\title{
Heavy snow loads in Finnish forests respond regionally asymmetrically to projected climate change
}

\author{
Ilari Lehtonen ${ }^{1}$, Matti Kämäräinen ${ }^{1}$, Hilppa Gregow ${ }^{1}$, Ari Venäläinen ${ }^{1}$, and Heli Peltola ${ }^{2}$ \\ ${ }^{1}$ Finnish Meteorological Institute, 00101 Helsinki, Finland \\ ${ }^{2}$ School of Forest Sciences, University of Eastern Finland, 80101 Joensuu, Finland \\ Correspondence to: Ilari Lehtonen (ilari.lehtonen@fmi.fi)
}

Received: 20 May 2016 - Published in Nat. Hazards Earth Syst. Sci. Discuss.: 6 July 2016

Revised: 26 September 2016 - Accepted: 27 September 2016 - Published: 17 October 2016

\begin{abstract}
This study examined the impacts of projected climate change on heavy snow loads on Finnish forests, where snow-induced forest damage occurs frequently. For snowload calculations, we used daily data from five global climate models under representative concentration pathway (RCP) scenarios RCP4.5 and RCP8.5, statistically downscaled onto a high-resolution grid using a quantile-mapping method. Our results suggest that projected climate warming results in regionally asymmetric response on heavy snow loads in Finnish forests. In eastern and northern Finland, the annual maximum snow loads on tree crowns were projected to increase during the present century, as opposed to southern and western parts of the country. The change was rather similar both for heavy rime loads and wet snow loads, as well as for frozen snow loads. Only the heaviest dry snow loads were projected to decrease over almost the whole of Finland. Our results are aligned with previous snowfall projections, typically indicating increasing heavy snowfalls over the areas with mean temperature below $-8^{\circ} \mathrm{C}$. In spite of some uncertainties related to our results, we conclude that the risk for snow-induced forest damage is likely to increase in the future in the eastern and northern parts of Finland, i.e. in the areas experiencing the coldest winters in the country. The increase is partly due to the increase in wet snow hazards but also due to more favourable conditions for rime accumulation in a future climate that is more humid but still cold enough.
\end{abstract}

\section{Introduction}

Forest damage caused by snow loading on trees occurs frequently in boreal environments. On the European level, estimates of the amount of timber damaged by snow during a typical year vary between one and 4 million $\mathrm{m}^{3}$ (Nykänen et al., 1997; Schelhaas et al., 2003). In addition to the northern parts of the continent, frequent snow damage in European forests occurs in central Europe and in mountainous regions, e.g. in the Alps and Pyrenees (Schelhaas et al., 2003; Martín-Alcón et al., 2010). In Finland, insurance companies have paid on average approximately EUR 0.5 million compensation annually within the last three decades due to snow damage of forests, which accounts for about $7 \%$ of the total indemnities paid for forest owners (Finnish Forest Research Institute, 2014). Thus, snow is among the most important abiotic stress factors in the Finnish forests after windstorms which account for about $77 \%$ of the forest damage compensated for by private insurance companies. In addition, snowdamaged trees occasionally seriously disrupt power transmission by bending or leaning over power lines. Trees damaged by snow are furthermore susceptible to insect attacks and other kinds of consequential damage (e.g. Schroeder and Eidmann, 1993; Schlyter et al., 2006).

Typical forms of snow damage in forests include breakage and bending of stems as well as uprooting when the soil is unfrozen (Petty and Worrell, 1981; Nykänen et al., 1997). The resistance of trees to snow is controlled by tree and stand characteristics. Trees with asymmetrical crowns are particularly susceptible to snow damage (Nykänen et al., 1997). Different tree species also typically suffer from different kind of damage. In general, conifers are often consid- 
ered to be most badly affected (Nykänen et al., 1997) but, for instance, birches are vulnerable for bending (Martiník and Mauer, 2012). Hence, possible climate-change-driven changes in tree species composition, favouring birches and Scots pine with the expense of Norway spruce (Kellomäki et al., 2008), may further affect the overall risk of snow damage in forests. Moreover, with the exception of uprooting in Norway spruce stands, unmanaged forests tend to be more susceptible to snow damage than managed forests (Päätalo, 2000).

The risk of snow damage is strongly dependent upon weather and climatological factors. Temperature influences the moisture content and snow attaches to tree crowns and branches most effectively when temperature is close to freezing point at the time of precipitation (Solantie, 1994). Hence, accretion of heavy wet snow poses the greatest risk. Moderate wind speeds enhance snow accumulation but strong winds dislodge most of the snow from the tree crowns. Topography also plays an important role in the occurrence of snow damage. The heaviest snow loads tend to accumulate on forests at high altitudes (e.g. Jalkanen and Konôpka, 1998), largely because rime accumulation is most efficient in places located above the surrounding terrain (Makkonen and Ahti, 1995), but also because of the orographic addition to precipitation.

The climate in northern Europe is projected to change considerably during the 21 st century due to increasing greenhouse-gas concentrations in the atmosphere (e.g. Räisänen and Ylhäisi, 2015). In winter, both temperature and precipitation are projected to increase with high confidence. This will evidently lead to changes in snow climate, having multiple effects on ecological systems (Callaghan et al., 2011). In the coldest areas, snowfall is generally projected to increase (Krasting et al., 2013; Räisänen, 2015) while over milder regions, a considerably larger fraction of total precipitation is expected to fall as liquid form in a warmer climate. How this anticipated change will affect the risk of snow damage for trees and infrastructure is not straightforward given the sensitive nature of snow accumulation to specific weather conditions (Strasser, 2008). Because different forest management options (e.g. the choice of regeneration method and tree species) alter the probabilities of various types of forest damage (Nykänen et al., 1997; Klopcic et al., 2009), accurate estimates for changes in conditions causing damage would be beneficial for adaptation purposes (Jönsson et al., 2015).

Kilpeläinen et al. (2010) estimated that the risk for snowinduced forest damage would decrease throughout Finland towards the end of the present century. However, Gregow et al. (2011) argued that because of decreasing soil frost supporting tree anchorage and increasing heavy snow loads, the risk of uprooting would increase in southern Finland and the risk for stem breakage would increase in northern Finland. In both studies, a cumulative snow-load model presented by Gregow et al. (2008), referred to hereafter as the G08 method, was applied. The G08 method estimates the amount of snow load on tree crowns by applying precipitation, temperature and wind speed observations as input. However, Lehtonen et al. (2014) showed that when the snow load is classified into different components (rime, dry snow, wet snow and frozen snow), the snow loads simulated by the G08 method correlate best with dry snow loads having little importance with regard to the forest damage. Therefore, it will be interesting to apply a more sophisticated method in studying the climate change impacts on heavy snow loads on tree crowns. This may also give a more in-depth look on the relative importance of different snow load types in the change.

In this study, we apply the snow load calculation and classification method used by Lehtonen et al. (2014), hereafter referred to as the FMI method. Our aim is to assess the climate change impacts on the occurrence of heavy snow loads on tree crowns in Finland. In order to compare our results to those of Kilpeläinen et al. (2010), we also apply the G08 method. We use daily data from five independent general circulation models (GCMs) participating in the Coupled Model Intercomparison Project (CMIP) phase 5 (Taylor et al., 2012) under representative concentration pathway (RCP) scenarios RCP4.5 and RCP8.5 (Thomson et al., 2011; Riahi et al., 2011) over the period 1980-2099. Before the snow-load calculations, the modelled values of used weather variables were downscaled onto a high-resolution $0.1^{\circ} \times 0.2^{\circ}$ latitude-longitude grid covering Finland by using a quantile-mapping technique. The comparison of results based on different GCMs instead of multi-model mean approach enabled us to assess the model-based uncertainty in the climate change response because different models simulate different changes in climate in response to the same radiative forcing.

\section{Materials and methods}

\subsection{Climate data}

We used daily data from five CMIP5 models listed in Table 1 over the period 1980-2099. The models were chosen on the basis of their ability to simulate present-day average monthly temperature and precipitation climatology in northern Europe and the availability of all required variables on a daily timescale. The variables used in this study were mean, maximum and minimum air temperature at $2 \mathrm{~m}$ height, mean relative humidity at $2 \mathrm{~m}$ height, mean wind speed at $10 \mathrm{~m}$ height and total precipitation. Simulations over the historical period until 2005 were combined with simulations under RCP4.5 and RCP8.5 emission scenarios for the period 20062099. The RCP8.5 (Riahi et al., 2011) is a high-emission scenario leading to a warming of global land areas by almost $5^{\circ} \mathrm{C}$ by 2100 on the basis of their multi-model mean (Collins et al., 2013). In the RCP4.5 scenario (Thomson et al., 2011), the radiative forcing stabilises at $4.5 \mathrm{~W} \mathrm{~m}^{-2}$ in 2100 and 
Table 1. CMIP5 models used in this study with information on the country of origin and resolution of the models (L refers to number of vertical levels, $\mathrm{T}$ to triangular truncation and $\mathrm{C}$ to cubed sphere).

\begin{tabular}{llll}
\hline Model & Country of origin & Resolution $($ lon $\times$ lat $)$, level & Reference \\
\hline CanESM2 & Canada & T63 $\left(1.875^{\circ} \times 1.875^{\circ}\right)$, L35 & von Salzen et al. (2013) \\
CNRM-CM5 & France & T127 $\left(1.4^{\circ} \times 1.4^{\circ}\right)$, L31 & Voldoire et al. (2013) \\
GFDL-CM3 & USA & $\mathrm{C} 48\left(2.5^{\circ} \times 2.0^{\circ}\right)$, L48 & Donner et al. (2011) \\
HadGEM2-ES & UK & $1.25^{\circ} \times 1.875^{\circ}$, L38 & Collins et al. (2011) \\
MIROC5 & Japan & T85 $\left(1.4^{\circ} \times 1.4^{\circ}\right)$, L40 & Watanabe et al. (2010) \\
\hline
\end{tabular}
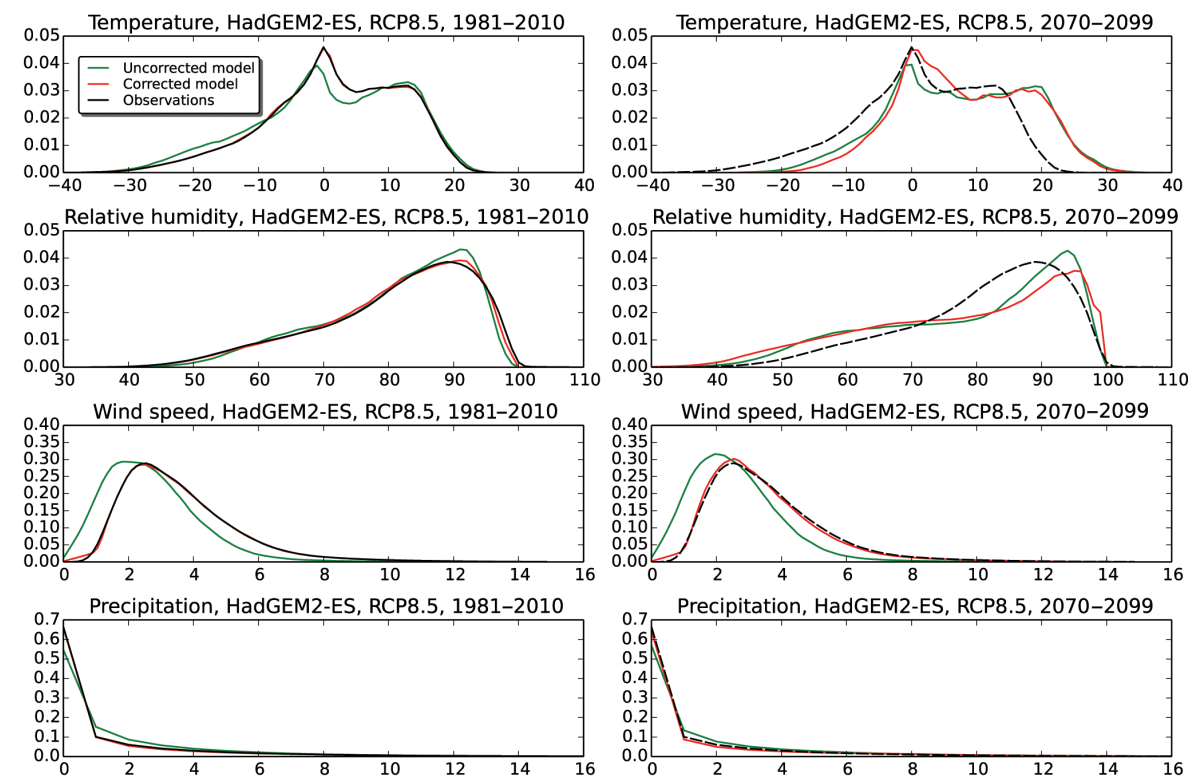

Figure 1. Probability distributions of daily mean $2 \mathrm{~m}$ air temperature $\left({ }^{\circ} \mathrm{C}\right)$, daily mean $2 \mathrm{~m}$ relative humidity $(\%)$, daily mean $10 \mathrm{~m}$ wind speed $\left(\mathrm{m} \mathrm{s}^{-1}\right)$ and daily total precipitation $(\mathrm{mm})$ in the HadGEM2-ES model for the periods 1981-2010 and 2070-2099 under the RCP8.5 scenario over the whole of Finland. Green curves represent the uncorrected model data and red curves the bias-corrected model data. Black curves represent the observational data during the calibration period 1981-2010. Dotted black curves display the observational probability distributions during the calibration period 1981-2010.

the warming on the global scale is about half of that in the RCP8.5 scenario (Collins et al., 2013). Over the Arctic areas and in Finland, the projected warming exceeds the global average due to Arctic amplification (Pithan and Mauritsen, 2014).

Before further data analysis, we performed a combined statistical downscaling and bias correction to the model data by applying a quantile mapping technique using smoothing. The model data were downscaled onto a regular $0.1^{\circ} \times 0.2^{\circ}$ grid (approximately $10 \mathrm{~km} \times 10 \mathrm{~km}$ ) covering Finland. In quantile mapping, cumulative probability distributions of simulated time series of weather variables are fitted to the observed distributions within the calibration period (19812010 in our case), separately for each month. For our observational data set, we used gridded data interpolated from the station observations made by the Finnish Meteorological Institute (FMI). The interpolation of station observations was done by applying Kriging with external drift (Aalto et al.,
2013). However, for wind speed, the quality of observations did not support the creation of a homogenous, gridded daily data set over Finland; therefore we used daily wind speeds from the European Centre for Medium-Range Weather Forecast ERA-Interim reanalysis (Dee et al., 2011) provided on a regular $0.75^{\circ} \times 0.75^{\circ}$ grid. The wind speeds were bilinearly interpolated onto the same $0.1^{\circ} \times 0.2^{\circ}$ grid with other variables but the true resolution was still much coarser for wind speed than for the other variables.

A detailed evaluation of quantile mapping for correcting simulated temperature time series was presented by Räisänen and Räty (2013) and for correcting simulated precipitation time series by Räty et al. (2014). Wilcke et al. (2013) also demonstrated the use of quantile mapping for correcting relative humidity and wind speed simulations of regional climate models. The effect of bias correction on simulated distributions of weather variables is exemplified in Fig. 1. For temperature, precipitation and wind speed, the corrected 
distributions correspond to the observed distributions within the calibration period by definition. Within scenario periods, the same corrections are applied to the simulated values than within the calibration period. Note that the peak in temperature distribution near the freezing point is retained both during the calibration and scenario periods whereas, for instance, the use of a simpler delta-change approach to scale the observed climate according to the simulated changes would unrealistically shift the peak.

For relative humidity, the correction was less accurate in freezing temperatures. That is because relative humidity in sub-zero temperatures can be expressed either relative to ice or supercooled water. The only difference between these two formulations is that the maximum possible water vapour content is assumed to be larger when humidity is expressed relative to supercooled water (Hardy, 1998). Hence, humidity of $100 \%$ relative to water in freezing temperatures would be over $100 \%$ relative to ice, but in nature these oversaturated situations with respect to ice rarely occur. For this reason, we performed the bias correction for humidities relative to ice to avoid non-physical oversaturated situations. Because in station observations humidity is expressed relative to water and in the model results relative to ice, we first transformed the observed humidities relative to ice following Hardy (1998). After the bias correction, the corrected distributions of humidity corresponded to the observed distributions relative to ice by definition. In the snow-load calculations, however, we needed the humidity to be expressed relative to water, thus we transformed the corrected humidities back to relative to water. After this final step, the corrected distributions of relative humidity did not necessarily correspond to the observed distributions. For some models the corrected and observed distributions were still close to each other but for part of the models the deviation was larger. It appeared that the annual maximum rime loads calculated from the corrected model data were, on average, approximately $20 \%$ larger than those calculated from the observational data during the calibration period 1981-2010 (not shown). This indicates that after the corrections, there were typically too many humid days at freezing temperatures.

We also note that conventional relative humidity measurements in freezing temperatures are not typically desirably accurate (Makkonen and Laakso, 2005). This was clear in our data as the observational relative humidities commonly had supersaturated values with respect to ice. However, after our bias correction, the humidity was not allowed to exceed $100 \%$ relative to ice. Moreover, part of the models had frequently unrealistic supersaturated humidities in sub-zero temperatures. We recognise that these inaccuracies in the observational humidity data and non-physicalities in the model data were a source of uncertainty in this study. It is, however, difficult to measure this type of uncertainty.

Projected wintertime (November-March) changes in climate variables in our data set after the bias correction are displayed in Fig. 2. Projections are shown separately for southern, central and northern Finland (Fig. 3). The division of Finland into subregions follows that by Lehtonen et al. (2014). Temperature and relative humidity with respect to water are generally projected to increase towards end of the century, the increase being larger in the north than in the south. For the relative humidity, this is partly because in subzero temperatures constant humidity relative to ice leads to increasing humidity relative to water with increasing temperature. Nevertheless, in southern Finland, relative humidity may even decrease. For temperature, the projected increase up to the end of the century is about $3-5^{\circ} \mathrm{C}$ under the RCP4.5 and about $5-9{ }^{\circ} \mathrm{C}$ under the RCP8.5 scenario compared to the baseline period 1980-2099, depending on the model and region. The projected change is only marginally larger for the traditional winter period from December to February. Precipitation is projected to increase rather uniformly throughout the country but the uncertainty ranges in the rate of the change are fairly large. Nonetheless, the projected changes are larger under the RCP8.5 than RCP4.5 scenario. Based on multi-model mean, mean wind speed is projected to stay almost unaltered. However, considerable variability in the projections exists between the models and one model suggests that mean wind speed could even increase by over $30 \%$ in central Finland.

\subsection{Crown snow load calculation methods}

We modelled the snow load amounts on tree crowns by applying the FMI method. This method has been developed at FMI for operational purposes as an early-warning tool for heavy snow loads on tree crowns mainly threatening the functionality of electric power network. A detailed description of the method was presented by Lehtonen et al. (2014) with discussion of the climatology of heavy crown snow loads in Finland. Lehtonen et al. (2014) moreover briefly evaluated the model performance with the help of a few example cases and observational data from one station. The model assumes an exemplar tree having a cone-shaped crown with a projected catchment area of $1 \mathrm{~m}^{2}$ from above and from the side in the direction of wind. One millimetre water layer of melted snow on a plain surface is furthermore assumed to correspond to $1 \mathrm{~kg} \mathrm{~m}^{-2}$ snow load on the tree crown.

In a nutshell, the modelled snow load is classified into four different types: rime, dry snow, wet snow and frozen snow. A decrease of the modelled snow load may occur due to wind removal or melting and the snow type may also change. The possible snow load type transformations are wet snow freezing into frozen snow and dry and frozen snow changing into wet snow. Increase of the snow load is caused by accumulation of rime and snowfall. Rime is the only snow load type in the model affected by relative humidity. Other variables needed in the model calculations are air temperature, precipitation, wind speed, global radiation and cloudiness. In producing the crown snow load climatology, Lehtonen et al. (2014) excluded the effects of solar radiation and cloudi- 
(a)

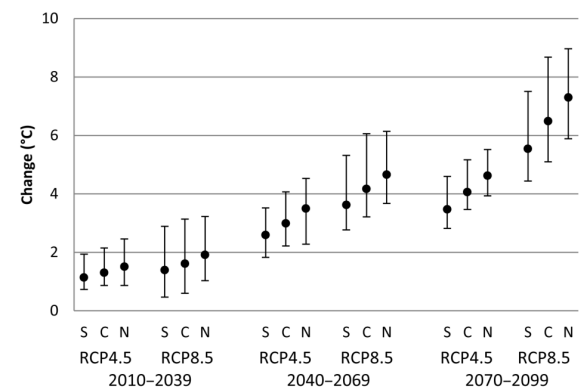

(c)

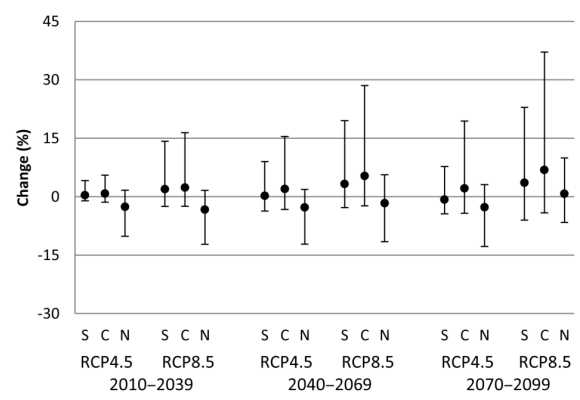

(b)

Relative humidity

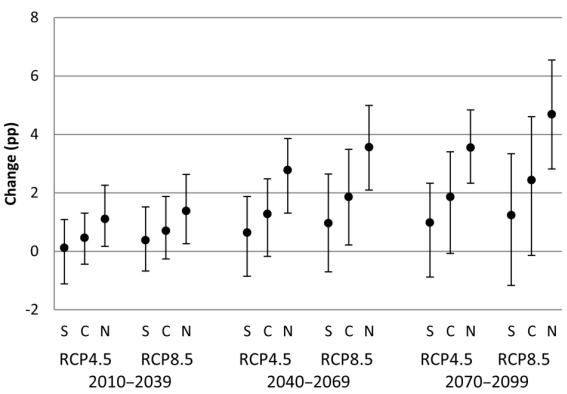

(d)

Precipitation

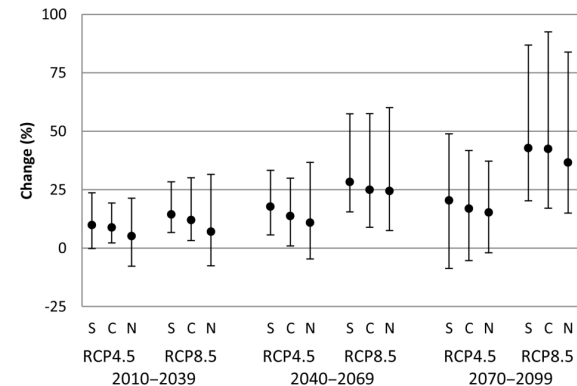

Figure 2. Projected changes in November-March mean $2 \mathrm{~m}$ air temperature (a), mean $2 \mathrm{~m}$ relative humidity (b), mean $10 \mathrm{~m}$ wind speed (c) and total precipitation (d) compared to the period 1980-2009 and averaged over southern (S), central (C) and northern (N) Finland. Dots indicate the multi-model mean change and whiskers extend to the maximum and minimum projections.

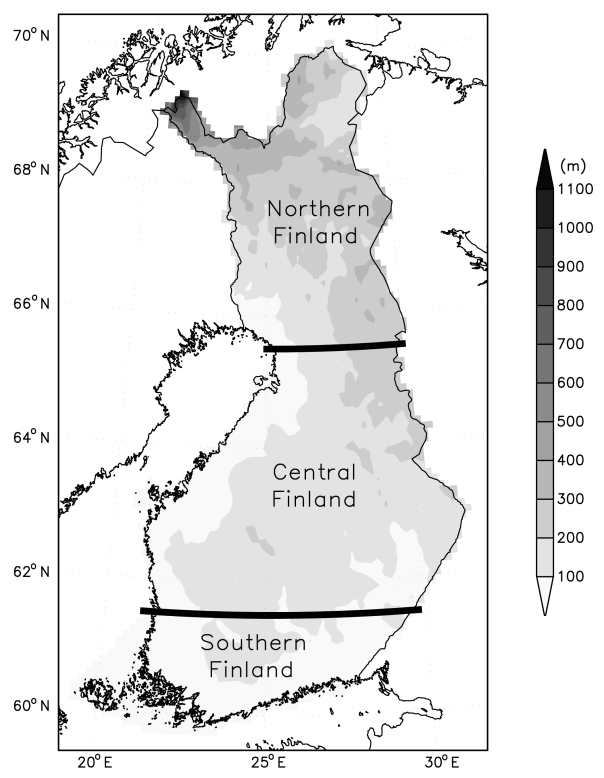

Figure 3. Division of Finland into southern, central and northern Finland. Shading shows the elevation above mean sea level. ness in the model because of a lack of sufficient observations. Here, we followed the same approach, which leads in some cases to too-intense riming and underestimation of snow removal in late winter (Lehtonen et al., 2014).

The FMI method has a time step of $1 \mathrm{~h}$ but according to Lehtonen et al. (2014), the snow load amounts calculated with daily mean data correlate on average rather well $(r \sim 0.8)$ with those calculated based on hourly or 3-hourly data, particularly in the case of rime and dry snow. In this study, we used only daily data but we mimicked diurnal cycle of $2 \mathrm{~m}$ temperature by assuming in the calculations daily minimum temperature to occur at 00:00 UTC and maximum temperature at 12:00 UTC. Similarly, we assumed that daily mean temperature prevailed at 06:00 and 18:00 UTC and that temperature changed linearly between these four moments. Other weather variables were assumed to stay constant throughout a day. Although the dependence between temperature and time of day in Finland in winter is weak, the artificially induced temperature cycle was expected to improve the results when temperature varied around the freezing point. Kilpeläinen et al. (2010) used a similar approach in their work by utilising the sine function in daily temperatures.

In addition to weather variables, the riming efficiency in the FMI model is influenced by topography. The modelled 
(a)

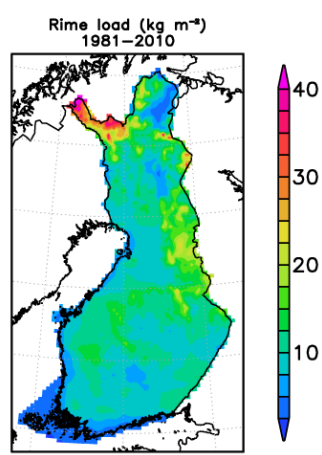

(e)

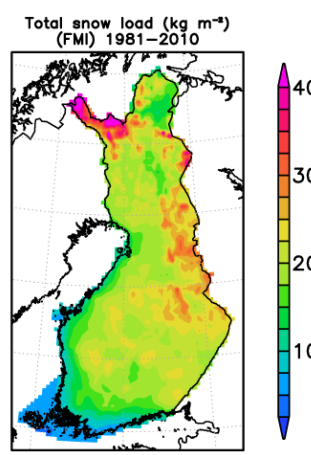

(b)

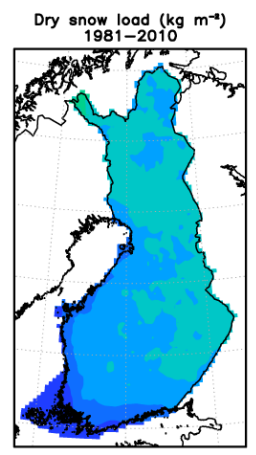

(f)

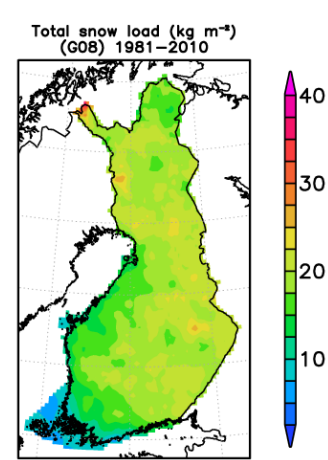

(c)
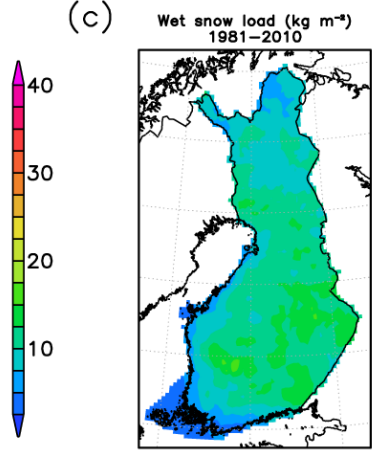

(g)

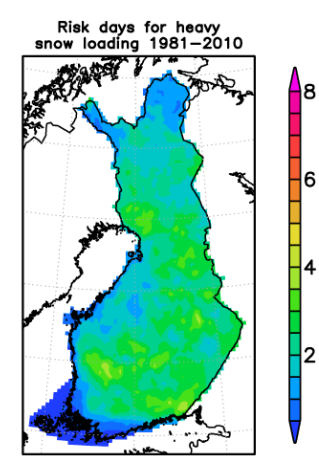

(d)

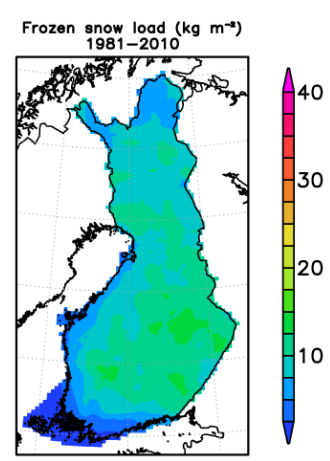

(h)

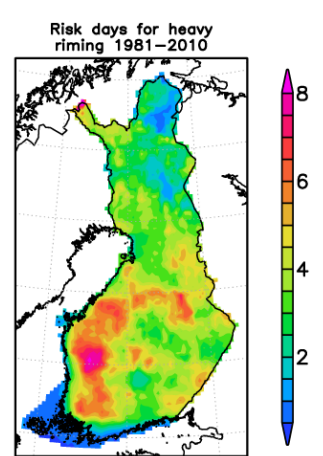

Figure 4. The annual maximum rime loads (a), dry snow loads (b), wet snow loads (c), frozen snow loads (d), total snow loads based on the FMI method (e) and total snow loads based on the G08 method (f) averaged over the period 1981-2010 and calculated from the observational weather data. The annual numbers of risk days for heavy snow loading (g) and heavy riming (h) are shown as well.

effectiveness of riming reaches its maximum value at elevation of $400 \mathrm{~m}$ a.m.s.l. (above mean sea level) (Lehtonen et al., 2014). The areas affected by enhanced riming include many areas in northern Finland and north-eastern central Finland (Fig. 3).

In order to compare our results to those by Kilpeläinen et al. (2010), we calculated the snow loads with the same G08 method (Gregow et al., 2008) that was used by Kilpeläinen et al. (2010). Compared to the FMI method, the G08 method is computationally far simpler. Its input variables are $2 \mathrm{~m}$ temperature, $10 \mathrm{~m}$ wind speed and precipitation. In this model, the snow load is increased by accumulation of snowfall and sleet when temperature is below $2.3^{\circ} \mathrm{C}$ and loss of snow due to wind removal and melting. The main deficiency of the G08 method is the exclusion of riming as, especially at high altitudes in northern Finland, rime accretion is the most important factor leading to heavy crown snow loads.

We also calculated the number of risk days for heavy rime and total snow load accretion based on daily mean values of $2 \mathrm{~m}$ air temperature, $2 \mathrm{~m}$ relative humidity, $10 \mathrm{~m}$ wind speed and precipitation. Here we used the thresholds (Table 2) defined by Lehtonen et al. (2014) based on weather observations and snow-load calculations for four stations across Finland. The number of risk days were studied to get a more robust idea of future changes in the risk of snow damage as, according to Lehtonen et al. (2014), the geographical distribution of number of risk days for heavy snow loading using these thresholds corresponds well with the geographical distribution of modelled heavy wet snow loads. However, for the risk days for heavy riming, the same kind of dependence did not hold true. The number of days expressing heavy rime accumulation was underestimated on coastal regions and at high altitudes based on the number of risk days, probably because the defined thresholds were not well suited in these areas.

\section{Results}

The annual maximum crown snow loads in Finland as averaged over the period 1981-2010 are shown in Fig. 4. The results are calculated from the observational daily data using both the FMI and G08 methods and the values are shown for the total crown snow load as well as for the different snow load types from the FMI method. The numbers of risk days for heavy snow loading and riming are displayed as well. The modelled annual maximum snow loads generally tend to be slightly heavier based on the FMI method than the G08 method, especially over the high-elevated areas where the modelled rime loads are heaviest. 
(a)

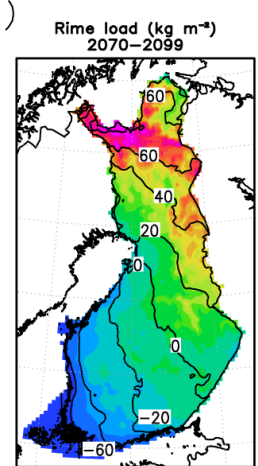

(e)

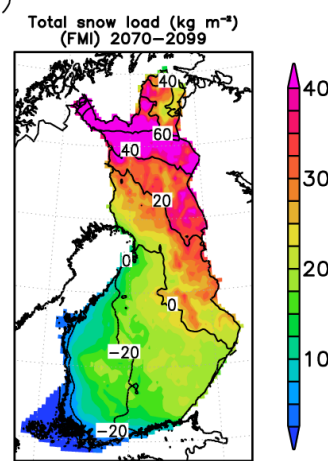

(b)

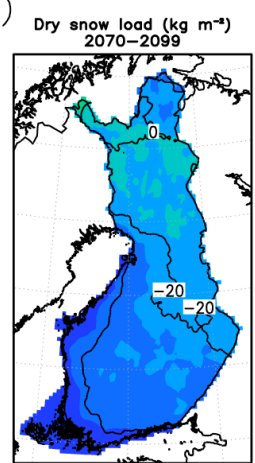

(f)

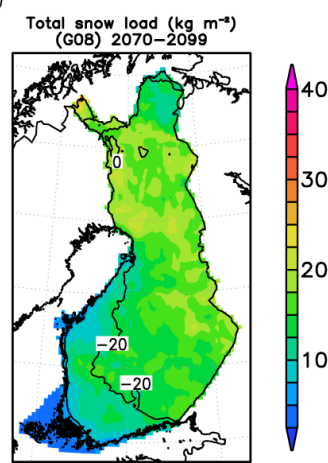

(c)
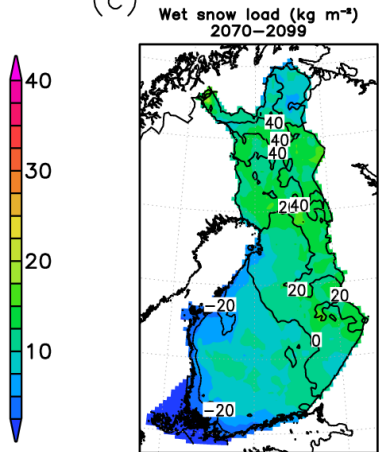

(

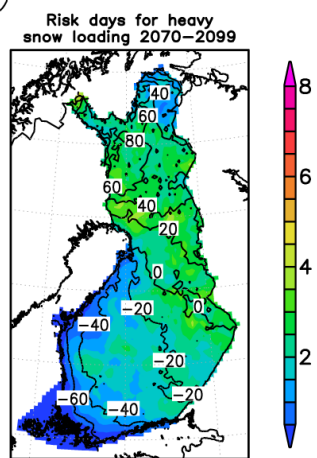

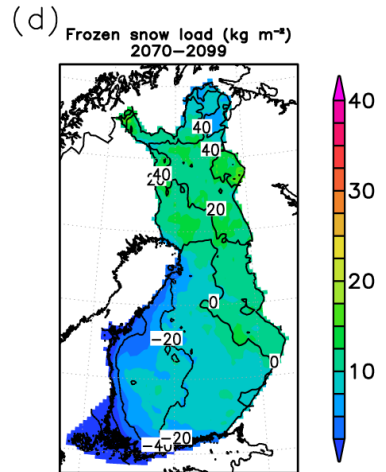

(h)

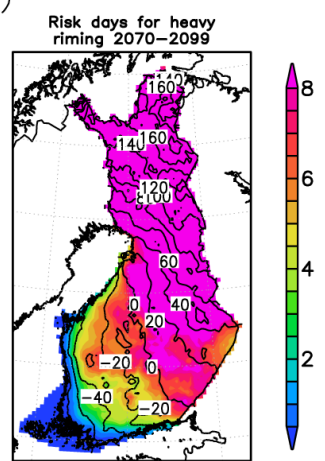

Figure 5. The annual maximum rime loads (a), dry snow loads (b), wet snow loads (c), frozen snow loads (d), total snow loads based on the FMI method (e) and total snow loads based on the G08 method (f) for the period 2070-2099 under the RCP8.5 scenario as a multi-model mean. Contours show the multi-model mean change from 1980-2009 to 2070-2099.

Table 2. Threshold values of daily $2 \mathrm{~m}$ mean air temperature $\left(T_{\text {mean }}\right), 2 \mathrm{~m}$ mean relative humidity $\left(\mathrm{RH}_{\text {mean }}\right), 10 \mathrm{~m}$ mean wind speed $\left(U_{\text {mean }}\right)$ and total precipitation $\left(P_{\text {day }}\right)$ determined by Lehtonen et al. (2014) for risk days favourable for heavy snow loading and heavy riming.

\begin{tabular}{ll}
\hline Risk days for heavy snow loading & Risk days for heavy riming \\
\hline$-3.4^{\circ} \mathrm{C}<T_{\text {mean }}<1.1^{\circ} \mathrm{C}$ & $-5 .{ }^{\circ} \mathrm{C}<T_{\text {mean }}<-0.2^{\circ} \mathrm{C}$ \\
$\mathrm{RH}_{\text {mean }}>89.4 \%$ & $\mathrm{RH}_{\text {mean }}>95.5 \%$ \\
$2.1 \mathrm{~m} \mathrm{~s}^{-1}<U_{\text {mean }}<5.6 \mathrm{~m} \mathrm{~s}^{-1}$ & $2.0 \mathrm{~m} \mathrm{~s}^{-1}<U_{\text {mean }}<4.5 \mathrm{~m} \mathrm{~s}^{-1}$ \\
$P_{\text {day }}>6.4 \mathrm{~mm}$ & $P_{\text {day }}<1.1 \mathrm{~mm}$ \\
\hline
\end{tabular}

The same variables for the future period 2070-2099 under the high-emission RCP8.5 scenario are shown in Fig. 5 as a multi-model mean, along with percentage changes to the period 1980-2009. The annual maximum rime loads, as well as wet snow and frozen snow loads are projected to increase in eastern and northern Finland up to $60 \%$ compared to the period 1980-2009. In southern and western Finland, the annual maximum snow loads are simultaneously projected to decrease. Projected changes for total snow load based on the FMI method closely resemble those for rime, wet snow and frozen snow loads. For dry snow, the annual maximum loads are projected to decrease across almost the whole of Finland. Only in northern Finland are they projected to remain roughly unaltered. The situation is similar for total snow loads calculated using the G08 method. Risk days for heavy snow loading are projected to change rather similarly to those for heavy wet snow loads. For intense riming, the favourable conditions are projected to become much more common in eastern and northern Finland.

The projected changes in the annual maximum values of different snow load components for all the three future periods 2010-2039, 2040-2069 and 2070-2099 compared to the period 1980-2009 are displayed in Fig. 6 as areal averages over southern, central and northern Finland. For the nearfuture period 2010-2039, the projected changes are small except in northern Finland, where annual maximum rime, wet snow and frozen snow loads are already projected to increase by about $10-30 \%$. For the more distant periods, not many additional increases in northern Finland are expected but in the south, the annual maximum crown snow loads are projected to start decreasing. In central Finland, the projected changes are on average rather small for all time periods and snow load components. The eastern parts of the region are nevertheless mainly experiencing increasing trends and western parts are experiencing decreasing trends (Fig. 5). In general, the area of decreasing trends slowly expands when moving to more distant future periods (not shown), Fig. 5 represents the most distant future period considered in this study. This 
(a)

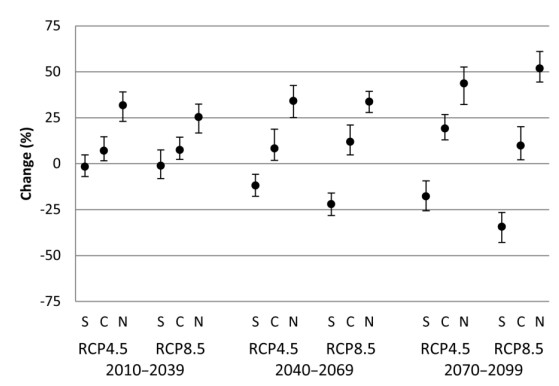

(c)

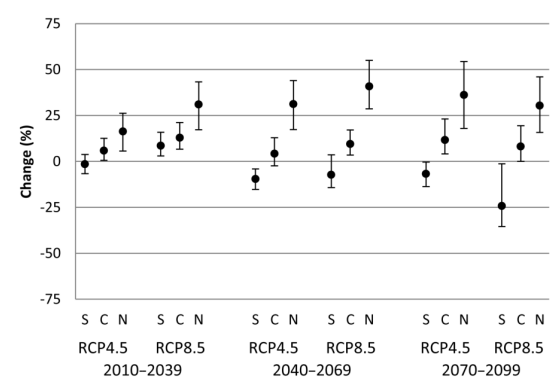

(e)

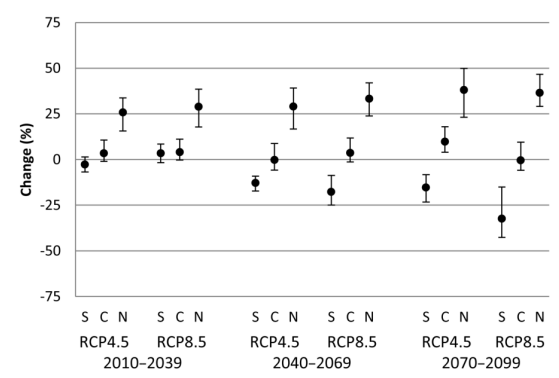

(b)

Dry snow load

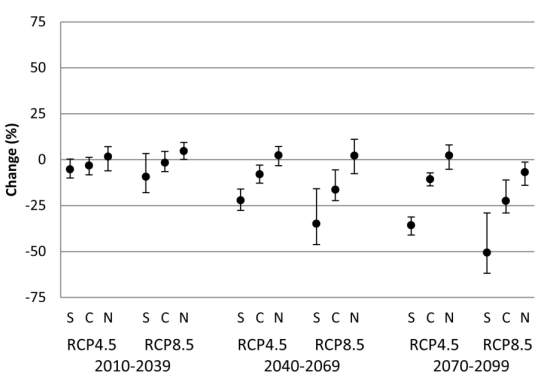

(d)

Frozen snow load

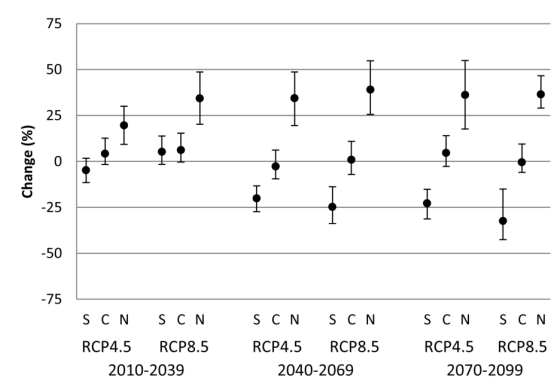

(f) Total snow load (G08)

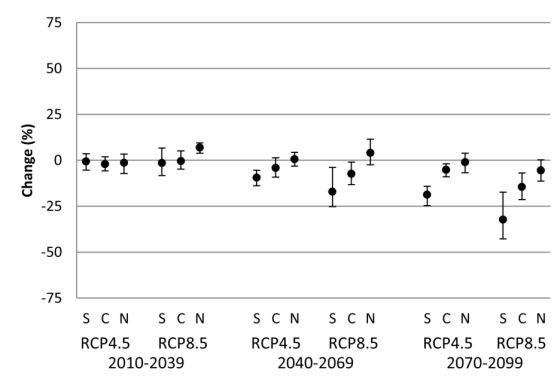

Figure 6. Projected changes in the annual maximum rime loads (a), dry snow loads (b), wet snow loads (c), frozen snow loads (d), total snow loads based on the FMI method (e) and total snow loads based on the G08 method (f) compared to the period 1980-2009 and averaged over southern $(\mathrm{S})$, central $(\mathrm{C})$ and northern $(\mathrm{N})$ Finland. Dots indicate the multi-model mean change and whiskers extend to the maximum and minimum projections.

non-linearity of the changes can be seen in Fig. 6. For instance, under the RCP8.5 scenario, the heavy wet snow loads and frozen snow loads are likely to slightly increase even in southern Finland at first but towards the end of the 21st century, they are projected to decrease by about $10-40 \%$. Similarly, the dry snow loads are at first projected to slightly increase in the north but rather decrease thereafter. Figure 6 moreover confirms the conclusion that projected changes in the total crown snow loads estimated by the G08 method mostly resemble those of dry snow loads estimated by the FMI method.

The uncertainty in the projections related to the model choice is fairly modest (Fig. 6). All models suggest the annual maximum snow loads will increase in the north with the exception of dry snow loads and total snow loads by the G08 method. Similarly, the annual maximum loads of all snow load types are projected to decrease in the south by all models by the end of the present century.

The numbers of risk days for heavy rime and total snow loading are mostly projected to decrease both in early and late winter (Fig. 7). During midwinter months, the numbers of risk days are projected to remain nearly unaltered in southern Finland, to increase slightly in central Finland and to increase considerably in northern Finland. Early winter would still be the most favourable time of year for heavy rime and snow accretion. But, for example, in northern Finland, December might be the most favourable month for riming in the future instead of November, and wet snow hazards could 
(a) Rime S Finland RCP4.5

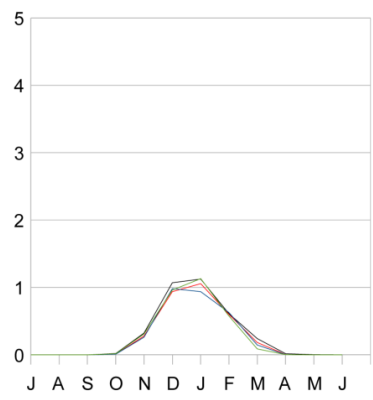

(e) Rime C Finland RCP4.5

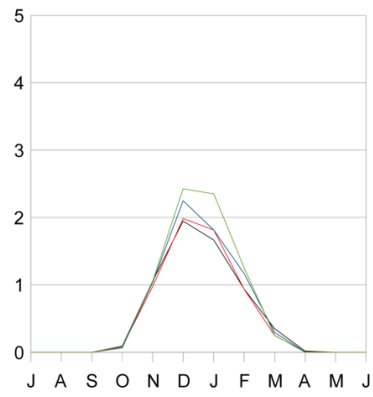

(i) Rime N Finland RCP4.5

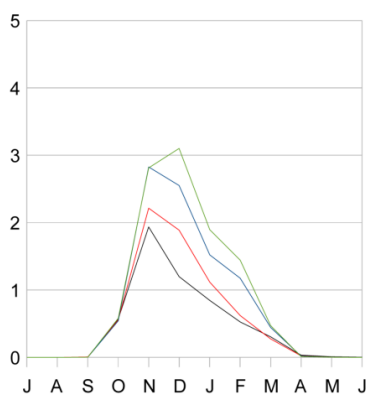

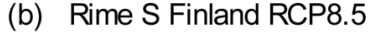

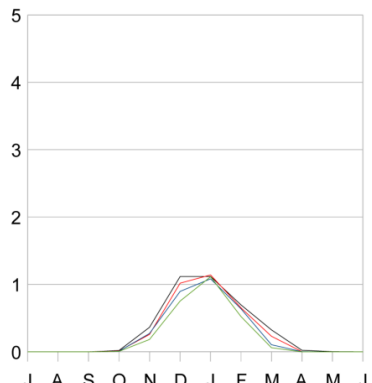

(f) Rime C Finland RCP8.5

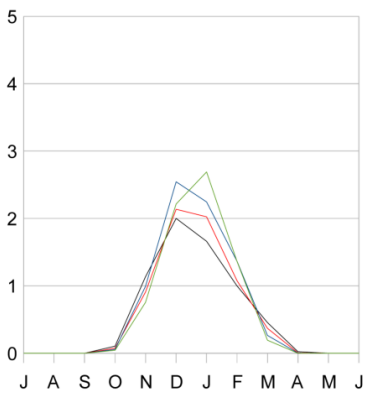

(j) Rime N Finland RCP8.5

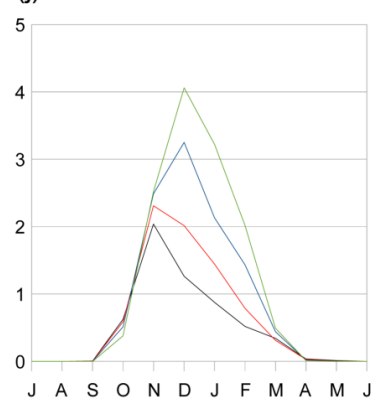

(c) Total load S Finland RCP4.5
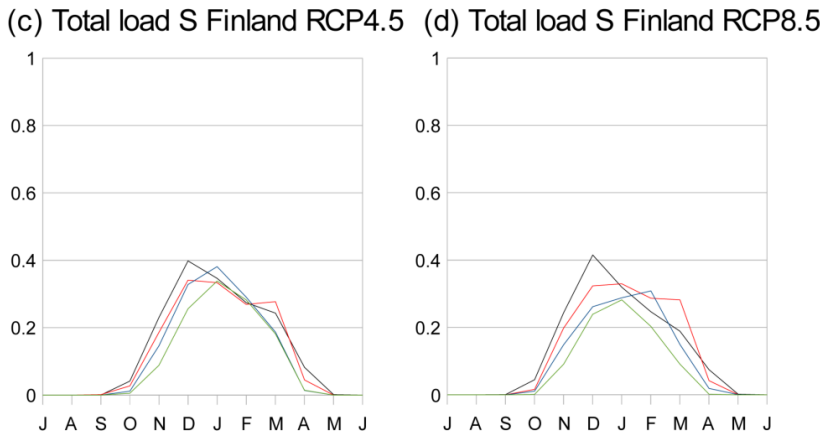

(g) Total load C Finland RCP4.5
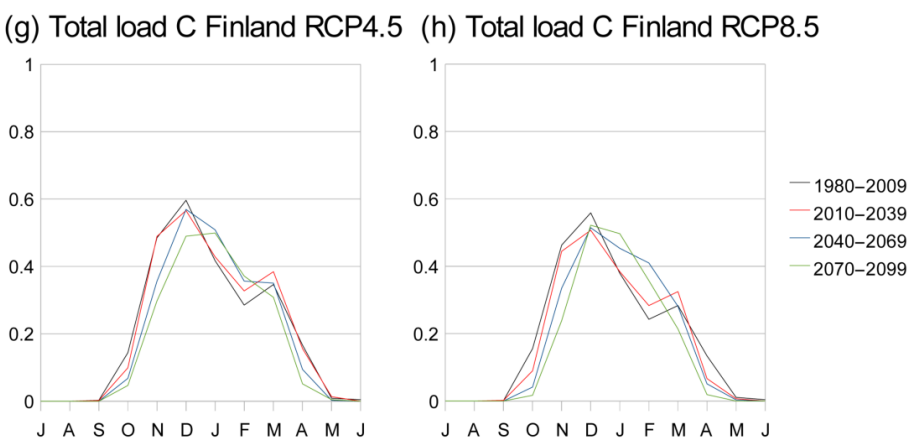

(k) Total load N Finland RCP4.5 (l) Total load N Finland RCP8.5

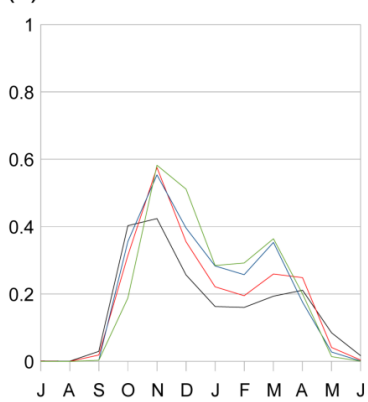

Figure 7. The annual numbers of risk days by month for heavy riming and heavy snow loading during 1980-2009 (black), 2010-2039 (red), 2040-2069 (blue) and 2070-2099 (green) under the RCP4.5 and RCP8.5 scenarios as averaged over southern (S; top row panels), central (C; middle row panels) and northern (N; bottom row panels) Finland.

occur most frequently in November and December instead of in October and November.

\section{Discussion}

There are many sources of uncertainty in our results. Firstly, the modelled amounts of snow loads on tree crowns are highly sensitive to the weather conditions near the freezing point. Hence, it is clear that the use of uncorrected model data being somewhat biased would not have been desirable in this study. Similarly, the feasibility of the applied bias correction method to our purposes is of utmost importance. We applied quantile mapping, which is a widely adopted technique in climate change impact studies and generally suggested for correcting model bias (Teutschbein and Seibert, 2012). It has, moreover, proven to be among the best-performing empirical bias-correction methods for temperature (Räisänen and Räty, 2013) and precipitation (Räty et al., 2014) throughout the probability distribution. On the other hand, bias correction alters spatio-temporal relations between different variables without satisfactory physical justification (Ehret et al., 2012). This adds uncertainty to our results as they are sensitive to a suitable combination of several weather variables. Bias correction of relative humidity was considered to be most uncertain. On the other hand, rime was the only snow type in the model affected by relative humidity but the projections for heavy rime loads should be treated cautiously.

Other noteworthy sources of uncertainty are the snow load models themselves. The deficiencies related to the applied methods were discussed earlier by Lehtonen et al. (2014). Again, reasonable modelling of rime loads was considered to be particularly uncertain. One reason for this was that 
properties of rime are sensitive to the formation conditions (e.g. Wang and Jiang, 2012). Moreover, as properties of individual trees vary greatly, it is not possible to use an exact and uniform snow-loading model. More sophisticated methods have been developed to model the risk of snow damage to single trees and forest stands (e.g. Valinger and Fridman, 1997; Peltola et al., 1999; Päätalo et al., 1999; Hlásny et al., 2011) as well as to model snow accumulation on power lines and other symmetrical objects (e.g. Makkonen and Wichura, 2010; Nygaard et al., 2013). As noted by Nygaard et al. (2013), the sticking efficiency of wet snowflakes is still quite inaccurate.

Additionally, in this study, the use of daily data was assumed to deteriorate the results. However, with the exception of considerably heavier rime loads in the north-westernmost Finland, the geographical distributions of modelled annual maximum snow loads closely resembled those presented by Lehtonen et al. (2014) by using 3-hourly station observations as input data. This suggests that climatological features of heavy crown snow loads were satisfactorily captured by using daily weather data. In fact, Lehtonen et al. (2014) hypothesised that the modelled rime loads were underestimated at high elevations in northern Finland due to too-efficient wind removal. While the resolution of our wind speed data was coarser compared to other variables, these deficiencies overruled each other in this study and possibly led to more a realistic simulation of rime loads in northern Finland. We further note that the heaviest rime loads were modelled over approximately the same areas which were recognised to be most susceptible for losses in wind energy production in Finland due to icing (Hämäläinen and Niemelä, 2016).

To estimate the model-based uncertainty related to the projections, we used data from five different climate models. The different models proved to produce fairly similar responses to the occurrence of heavy crown snow loads, consisting mainly of an increase in the annual maximum snow loads in eastern and northern Finland and a decrease in southern and western Finland. Moreover, the projected changes for different snow load types had rather similar geographical characteristics with the exception of dry snow loads which were projected to decrease almost over the whole of Finland. A similar decrease in the risk was evident by using the simpler G08 method, as previously suggested by Kilpeläinen et al. (2010). The lack of division of snow load into different types and complete omitting of riming are the major deficiencies in the G08 method compared to the FMI method. In overall, the differences in our results compared to those of Kilpeläinen et al. (2010) are attributable to the different calculation methods of snow loads while the climate change impact itself was fairly similar in these two studies.

Based on an ensemble of regional climate model simulations, Räisänen (2016) showed recently that snowfall in northern Europe is typically projected to decrease in a warming climate everywhere where mean temperature exceeds $-11^{\circ} \mathrm{C}$. However, snowfall extremes occur in similar con- ditions with near-zero temperatures regardless of climate warming, thus changes in the frequency of those conditions are relevant to heavy snow loads. Hence, fewer systematic changes have been simulated for the intensity of extreme daily snowfall than for total snowfall (O'Gorman, 2014; Räisänen, 2016). As seen in Fig. 1, near-zero temperatures may occur in the future as frequently as they do currently in spite of general warming. According to previous model studies (de Vries et al., 2014; Räisänen, 2016), the maximum snowfall decreases over the areas where mean temperature exceeds $-8^{\circ} \mathrm{C}$. This is more or less in agreement with our projections for heavy wet snow loads as they are projected to increase roughly over the area where the mean temperature of midwinter months from December to February is below $-8^{\circ} \mathrm{C}$ in the current climate (Pirinen et al., 2012). In further accordance with the present results, Räisänen (2016) also noted a similar change in snowfall seasonality which is apparent in the number of risk days for heavy snow loading: in northern Fennoscandia, snowfall is projected to increase between December and March and to decrease during early and late winter.

\section{Conclusions}

The impact of projected climate change on heavy snow loads on tree crowns in Finland was studied in this work by using the statistically downscaled and bias-corrected daily output of five CMIP5 models. Our results indicate that while climate becomes warmer, the annual maximum snow loads are likely to increase in eastern and northern Finland while in the southern and western parts of the country they are expected to decrease. This implies that there exists an increasing need to consider risks of snow damage in forest management in eastern and northern Finland. Our results contradict those by Kilpeläinen et al. (2010), suggesting that the risk for snow damage would decrease in the whole of Finland towards end of this century. This difference is attributable to differences in used snow load calculation methods. By dividing the snow load into different components, namely rime, dry snow, wet snow and frozen snow, it was demonstrated that only dry snow loads are projected to change similarly with the projections presented by Kilpeläinen et al. (2010). Our results, moreover, are in agreement with those of Räisänen (2016), showing that heavy snowfalls in northern Europe are likely to increase over the areas experiencing the coldest winters.

Our results are affected by many sources of uncertainty. The main challenge in modelling crown snow loads is that the accumulation of snow and rime is sensitive to small variations in multiple weather variables. For instance, snowfall accumulates on tree branches and crowns most effectively within a narrow temperature range around $0^{\circ} \mathrm{C}$. Hence, our results are fairly sensitive to the applied bias-correction procedures. The modelling of rime loads was considered to be most uncertain, mostly due to uncertainties related to cor- 
recting relative humidity. However, the projected changes for the annual maximum rime loads proved to be fairly similar to those for wet and frozen snow loads. Hence, we believe that these results will serve as a valuable basis for anticipated changes in risks for snow damage in Finnish forests.

\section{Data availability}

Registered users can download the climate model data from the CMIP archive at http://pcmdi9.1lnl.gov/. The ERAInterim data can be obtained from the European Centre for Medium-Range Weather Forecasts data server at http://apps. ecmwf.int/datasets/. The observational gridded weather data produced by the FMI is available at http://avaa.tdata.fi/web/ paituli/metadata.

Acknowledgements. This research has been supported by the Consortium project ADAPT (Adaptation of forest management to climate change: uncertainties, impacts, and risks to forests and forestry in Finland), which is a collaboration project between the University of Eastern Finland (UEF proj. 14907) and FMI (proj. 260785) and funded jointly by the Academy of Finland, UEF and FMI. Support was also received from the Strategic Research Council at the Academy of Finland through the FORBIO (Sustainable, climate-neutral, and resource-efficient forest-based bioeconomy) project. We acknowledge the World Climate Research Programme's Working Group on Coupled Modelling, which is responsible for CMIP, and we thank the climate modelling groups (listed in Table 1 of this paper) for producing and making their model output available. For CMIP the US Department of Energy's Program for Climate Model Diagnosis and Intercomparison provides coordinating support and led development of software infrastructure in partnership with the Global Organization for Earth System Science Portals. The ERA-Interim data were obtained from the European Centre for Medium-Range Weather Forecasts data server. The development of the FMI method is based on the work of Petri Hoppula, Reijo Solantie, Mika Heiskanen, Kari Ahti, Bengt Tammelin and Kristiina Säntti at FMI. We thank Kimmo Ruosteenoja for downloading and preprocessing the model data. Pentti Pirinen is acknowledged for interpolating the observational data onto the Finnish grid. We appreciate Olle Räty and Jouni Räisänen from Department of Physics, University of Helsinki, for developing the applied bias correction software.

Edited by: S. Fuchs

Reviewed by: two anonymous referees

\section{References}

Aalto, J., Pirinen, P., Heikkinen, J. and Venäläinen, A.: Spatial interpolation of monthly climate data for Finland: comparing the performance of kriging and generalized additive models, Theor. Appl. Climatol., 112, 99-111, doi:10.1007/s00704-012-0716-9, 2013.

Callaghan, T. V., Johansson, M., Brown, R. D., Groisman, P. Y., Labba, N., Radionov, V., Bradley, R. S., Blangy, S., Bulygina, O. N., Christensen, T. R., Colman, J. E., Essery, R. L. H., Forbes, B. C., Forchhammer, M. C., Golubev, V. N., Honrath, R. E., Juday, G. P., Meshcherskaya, A. V., Phoenix, G. K., Pomeroy, J., Rautio, A., Robinson, D. A., Schmidt, N. M., Serreze, M. C., Shevchenko, V. P., Shiklomanov, A. I., Shmakin, A. B., Sköld, P., Sturm, M., Woo, M., and Wood, E. F.: Multiple effects of changes in Arctic snow cover, Ambio, 40, 32-45, doi:10.1007/s13280011-0213-x, 2011.

Collins, M., Knutti, R., Arblaster, J., Dufresne, J.-L., Fichefet, T., Friedlingstein, P., Gao, X., Gutowski, W. J., Johns, T., Krinner, G., Shongwe, M., Tebaldi, C., Weaver, A. J., and Wehner, M.: Long-term climate change: projections, commitments and irreversibility, in: The Physical Science Basis, Contribution of Working Group I to the Fifth Assessment Report of the Intergovernmental Panel on Climate Change, edited by: Stocker, T. F., Qin, D., Plattner, G.-K., Tignor, M., Allen, S. K., Boschung, J., Nauels, A., Xia, Y., Bex, V. and Midgley, P. M., Cambridge University Press, Cambridge and New York, 1029-1136, 2013.

Collins, W. J., Bellouin, N., Doutriaux-Boucher, M., Gedney, N., Halloran, P., Hinton, T., Hughes, J., Jones, C. D., Joshi, M., Liddicoat, S., Martin, G., O'Connor, F., Rae, J., Senior, C., Sitch, S., Totterdell, I., Wiltshire, A., and Woodward, S.: Development and evaluation of an Earth-System model - HadGEM2, Geosci. Model Dev., 4, 1051-1075, doi:10.5194/gmd-4-10512011, 2011.

Dee, D. P., Uppala, S. M., Simons, A. J., Berrisford, P., Poli, P., Kobayashi, S., Andrae, U., Balmaseda, M. A., Balsamo, G., Bauer, P., Bechtold, P., Beljaars, A. C. M., van de Berg, L., Bidlot, J., Bormann, N., Delsol, C., Dragani, R., Fuentes, M., Geer, A. J., Haimberger, L., Healy, S. B., Hersbach, H., Hólm, E. V., Isaksen, L., Kållberg, P., Köhler, M., Matricardi, M., McNally, A. P., Monge-Sanz, B. M., Morcrette, J.-J., Park, B.-K., Peubey, C., de Rosnay, P., Tavolato, C., Thépaut, J.-N., and Vitart, F.: The ERA-Interim reanalysis: configuration and performance of the data assimilation system, Q. J. Roy. Meteorol. Soc., 137, 553597, doi:10.1002/qj.828, 2011.

de Vries, H., Lenderink, G., and van Meijgaard, E.: Future snowfall in western and central Europe projected with a high-resolution regional climate model ensemble, Geophys. Res. Lett., 41, 42944299, doi:10.1002/2014GL059724, 2014.

Donner, L. J., Wyman, B. L., Hemler, R. S., Horowitz, L. W., Ming, Y., Zhao, M., Golaz, J.-C., Ginoux, P., Lin, S.-J., Schwarzkopf, M. D., Austin, J., Alaka, G., Cooke, W. F., Delworth, T. L., Freidenreich, S. M., Gordon, C. T., Griffies, S. M., Held, I. M., Hurlin, W. J., Klein, S. A., Knutson, T. R., Langenhorst, A. R., Lee, H.-C., Lin, Y., Magi, B. I., Malyshev, S. L., Milly, P. C. D., Naik, V., Nath, M. J., Pincus, R., Ploshay, J. J., Ramaswamy, V., Seman, C. J., Shevliakova, E., Sirutis, J. J., Stern, W. F., Stouffer, R. J., Wilson, R. J., Winton, M., Wittenberg, A. T., and Zeng, F.: The dynamical core, physical parameterizations, and basic simulation characteristics of the atmospheric component AM3 of the 
GFDL global coupled model CM3, J. Climate, 24, 3484-3519, doi:10.1175/2011JCLI3955.1, 2011.

Ehret, U., Zehe, E., Wulfmeyer, V., Warrach-Sagi, K., and Liebert, J.: Should we apply bias correction to global and regional climate model data?, Hydrol. Earth Syst. Sci. 16, 3391-3404, doi:10.5194/hess-16-3391-2012, 2012.

Finnish Forest Research Institute: Finnish Statistical Yearbook of Forestry, Tammerprint, Tampere, 2014.

Gregow, H., Puranen, U., Venäläinen, A., Peltola, H., Kellomäki, S., and Schultz, D.: Temporal and spatial occurrence of strong winds and large snow load amounts in Finland during 1961-2000, Silva Fenn., 42, 515-534, doi:10.14214/sf.231, 2008.

Gregow, H., Peltola, H., Laapas, M., Saku, S., and Venäläinen, A.: Combined occurrence of wind, snow loading and soil frost with implications for risks to forestry in Finland under the current and changing climatic conditions, Silva Fenn., 45, 35-54, doi:10.14214/sf.30, 2011.

Hämäläinen, K. and Niemelä, S.: Production of a numerical icing atlas for Finland, Wind Energy, doi:10.1002/we.1998, in press, 2016.

Hardy, B.: ITS-90 formulations for vapor pressure, frostpoint temperature, dewpoint temperature, and enhancement factors in the range -100 to $+100^{\circ} \mathrm{C}$, Vol. 1, Papers and Abstracts from the Third International Symposium on Humidity \& Moisture, April 1998, England, 214-222, 1998.

Hlásny, T., Kř́stek, Š., Holuša, J., Trombik, J., and Urbaňcová, N.: Snow disturbances in secondary Norway spruce forests in Central Europe: regression modelling and its implications for forest management, Forest Ecol. Manage., 262, 2151-2161, doi:10.1016/j.foreco.2011.08.005, 2011.

Jalkanen, R. and Konôpka, B.: Snow-packing as a potential harmful factor on Picea abies, Pinus sylvestris and Betula pubescens at high altitude in northern Finland, Eur. J. Forest Pathol., 28, 373 382, doi:10.1111/j.1439-0329.1998.tb01191.x, 1998.

Jönsson, A. M., Lagergren, F., and Smith, B.: Forest management facing climate change - an ecosystem model analysis of adaptation strategies, Mitig. Adapt. Strateg. Glob. Change, 20, 201220, doi:10.1007/s11027-013-9487-6, 2015.

Kellomäki, S., Peltola, H., Nuutinen, T., Korhonen, K. T., and Strandman, H.: Sensitivity of managed boreal forests in Finland to climate change, with implications for adaptive management, Philos. T. Roy. Soc. B, 363, 2341-2351, doi:10.1098/rstb.2007.2204, 2008.

Kilpeläinen, A., Gregow, H., Strandman, H., Kellomäki, S., Venäläinen, A., and Peltola, H.: Impacts of climate change on the risk of snow-induced forest damage in Finland, Climatic Change, 99, 193-209, doi:10.1007/s10584-009-9655-6, 2010.

Klopcic, M., Poljanec, A., Gartner, A., and Boncina, A.: Factors related to natural disturbances in mountain Norway spruce (Picea abies) forests in the Julian Alps, Ecoscience, 16, 48-57, doi:10.2980/16-1-3181, 2009.

Krasting, J. P., Broccoli, A. J., Dixon, K. W., and Lanzante, J. R.: Future changes in Northern Hemisphere snowfall, J. Climate, 26, 7813-7828, doi:10.1175/JCLI-D-12-00832.1, 2013.

Lehtonen, I., Hoppula, P., Pirinen, P., and Gregow, H.: Modelling crown snow loads in Finland: a comparison of two methods, Silva Fenn., 48, 1120, doi:10.14214/sf.1120, 2014.
Makkonen, L. and Ahti, K.: Climatic mapping of ice loads based on airport weather observations, Atmos. Res., 36, 185-193, doi:10.1016/0169-8095(94)00034-B, 1995.

Makkonen, L. and Laakso, T.: Humidity measurements in cold and humid environments, Bound.-Lay. Meteorol., 116, 131-147, doi:10.1007/s10546-004-7955-y, 2005.

Makkonen, L. and Wichura, B.: Simulating wet snow loads on power line cables by a simple model, Cold Reg. Sci. Technol., 61, 73-81, doi:10.1016/j.coldregions.2010.01.008, 2010.

Martín-Alcón, S., González-Olabarria, J. R., and Coll, L.: Wind and snow damage in the Pyrenees pine forests: effect of stand attributes and location, Silva Fenn., 44, 399-410, doi:10.14214/sf.138, 2010.

Martiník, A. and Mauer, O.: Snow damage to birch stands in Northern Moravia, J. Forest Sci., 58, 181-192, 2012.

Nygaard, B. E. K., Ágústsson, H., and Somfalvi-Tóth, K.: Modeling wet snow accretion on power lines: improvements to previous methods using 50 years of observations, J. Appl. Meteorol. Clim., 52, 2189-2203, doi:10.1175/JAMC-D-12-0332.1, 2013.

Nykänen, M.-L., Peltola, H., Quine, C. P., Kellomäki, S., and Broadgate, M.: Factors affecting snow damage of trees with particular reference to European conditions, Silva Fenn., 31, 193213, 1997.

O'Gorman, P. A.: Contrasting responses of mean and extreme snowfall to climate change, Nature, 512, 416-418, doi:10.1038/nature13625, 2014.

Päätalo, M.-L.: Risk of snow damage in unmanaged and managed stands of Scots pine, Norway spruce and birch, Scand. J. Forest Res., 15, 530-541, doi:10.1080/028275800750173474, 2000.

Päätalo, M.-L., Peltola, H., and Kellomäki, S.: Modelling the risk of snow damage to forests under short-term snow loading, Forest Ecol. Manage., 116, 51-70, doi:10.1016/S0378-1127(98)004460, 1999.

Peltola, H., Kellomäki, S., Väisänen, H., and Ikonen, V.-P.: A mechanistic model for assessing the risk of wind and snow damage to single trees and stands of Scots pine, Norway spruce, and birch, Can. J. Forest Res., 29, 647-661, doi:10.1139/x99-029, 1999.

Petty, J. A. and Worrell, R.: Stability of coniferous tree stems in relation to damage by snow, Forestry, 54, 115-128, doi:10.1093/forestry/54.2.115, 1981.

Pirinen, P., Simola, H., Aalto, J., Kaukoranta, J.-P., Karlsson, P., and Ruuhela, R.: Climatological statistics of Finland 1981-2010, Finnish Meteorological Institute, Helsinki, 2012.

Pithan, F. and Mauritsen, T.: Arctic amplification dominated by temperature feedbacks in contemporary climate models, Nat Geosci., 7, 181-184, doi:10.1038/ngeo2071, 2014.

Räisänen, J.: Twenty-first century changes in snowfall climate in Northern Europe in ENSEMBLES regional climate models, Clim. Dynam., 46, 339-353, doi:10.1007/s00382-015-2587-0, 2016.

Räisänen, J. and Räty, O.: Projections of daily mean temperature variability in the future: cross-validation tests with ENSEMBLES regional climate models, Clim. Dynam., 41, 1553-1568, doi:10.1007/s00382-012-1515-9, 2013.

Räisänen, J. and Ylhäisi, J. S.: $\mathrm{CO}_{2}$-induced climate change in northern Europe: CMIP2 versus CMIP3 versus CMIP5, Clim. Dynam., 45, 1877-1897, doi:10.1007/s00382-014-2440-x, 2015.

Räty, O., Räisänen, J., and Ylhäisi, J. S.: Evaluation of delta change and bias correction methods for future daily precipitation: inter- 
modal cross-validation using ENSEMBLES simulations, Clim. Dynam., 42, 2287-2303, doi:10.1007/s00382-014-2130-8, 2014.

Riahi, K., Rao, S., Krey, V., Cho, C., Chirkov, V., Fischer, G., Kindermann, G., Nakicenovic, N., and Rafaj, P.: RCP8.5 - a scenario of comparatively high greenhouse gas emissions, Climatic Change, 109, 33-57, doi:10.1007/s10584-011-0149-y, 2011.

Schelhaas, M.-J., Nabuurs, G.-J., and Schuck, A.: Natural disturbances in the European forests in the 19th and 20th centuries, Global Change Biol., 9, 1620-1633, doi:10.1046/j.13652486.2003.00684.x, 2003.

Schlyter, P., Stjernquist, I., Bärring, L., Jönsson, A. M., and Nilsson, C.: Assessment of the impacts of climate change and weather extremes on boreal forests in northern Europe, focusing on Norway spruce, Clim. Res., 31, 75-84, doi:10.3354/cr031075, 2006.

Schroeder, L. M. and Eidmann, H. H.: Attacks of barkand wood-boring Coleoptera on snow-broken conifers over a two-year period, Scand. J. Forest Res., 8, 257-265, doi:10.1080/02827589309382775, 1993.

Solantie, R.: Effect of weather and climatological background on snow damage of forests in Southern Finland in November 1991, Silva Fenn., 28, 203-211, 1994.

Strasser, U.: Snow loads in a changing climate: new risks?, Nat. Hazards Earth Syst. Sci., 8, 1-8, doi:10.5194/nhess-8-1-2008, 2008.

Taylor, K. E., Stouffer, R. J., and Meehl, G. A.: An overview of CMIP5 and the experimental design, B. Am. Meteorol. Soc., 93, 485-498, doi:10.1175/BAMS-D-11-00094.1, 2012.

Teutschbein, C. and Seibert, J.: Bias correction of regional climate model simulations for hydrological climate-change impact studies: review and evaluation of different methods, J. Hydrol., 456457, 12-29, doi:10.1016/j.jhydrol.2012.05.052, 2012.

Thomson, A. M., Calvin, K. V., Smith, S. J., Kyle, P., Volke, A., Patel, P., Delgado-Arias, S., Bond-Lamberty, B., Wise, M. A., Clarke, L. E., and Edmonds, J. A.: RCP4.5: a pathway for stabilization of radiative forcing by 2100 , Climatic Change, 109 , 77-94, doi:10.1007/s10584-011-0151-4, 2011.
Valinger, E. and Fridman, J.: Modelling probability of snow and wind damage in Scots pine stands using tree characteristics, Forest Ecol. Manage., 97, 215-222, doi:10.1016/S03781127(97)00062-5, 1997.

Voldoire, A., Sanchez-Gomez, E., Salas y Mélia, D., Decharme, B., Cassou, C., Sénési, S., Valcke, S., Beau, I., Alias, A., Chevallier, M., Déqué, M., Deshayes, J., Douville, H., Fernandez, E., Madec, G., Maisonnave, E., Moine, M.-P., Planton, S., SaintMartin, D., Szopa, S., Tyteca, S., Alkama, R., Belamari, S., Braun, A., Coquart, L., and Chauvin, F.: The CNRM-CM5.1 global climate model: description and basic evaluation, Clim. Dynam., 40, 2091-2121, doi:10.1007/s00382-011-1259-y, 2013.

von Salzen, K., Scinocca, J. F., McFarlane, N. A., Li, J., Cole, J. N. S., Plummer, D., Verseghy, D., Reader, M. C., Ma, X., Lazare, M., and Solheim, L.: The Canadian fourth generation atmospheric global climate model (CanAM4). Part I: representation of physical processes, Atmos. Ocean, 51, 104-125, doi:10.1080/07055900.2012.755610, 2013.

Wang, S. and Jiang, X.: Progress in research on ice accretion on overhead transmission lines and its influence on mechanical and insulating performance, Front. Elect. Electron. Eng., 7, 326-336, doi:10.1007/s11460-012-0197-8, 2012.

Watanabe, M., Suzuki, T., O'ishi, R., Komuro, Y., Watanabe, S., Emori, S., Takemura, T., Chikira, M., Ogura, T., Sekiguchi, M., Takata, K., Yamazaki, D., Yokohata, T., Nozawa, T., Hasumi, H., Tatebe, H., and Kimoto, M.: Improved climate simulation by MIROC5: mean states, variability, and climate sensitivity, J. Climate, 23, 6312-6335, doi:10.1175/2010JCLI3679.1, 2010.

Wilcke, R. A. I., Mendlik, T., and Gobiet, A.: Multi-variable error correction of regional climate models, Climatic Change, 120, 871-887, doi:10.1007/s10584-013-0845-x, 2013. 